\title{
Supplementation and Change of Nutritional Habits for the Prevention and Treatment of Iron Deficiency Anaemia in Gaza Children: A Case Study
}

\author{
Michele Magoni, Ghassam Zaqout, Omar Ahmmed Mady, \\ Reema Ibraheem Al Haj Abed and Davide Amurri \\ Terre des Hommes \\ Italy
}

\section{Introduction}

Iron deficiency anaemia (IDA) is one of the most severe and widespread nutritional disorders in the world. Children and pregnant women in resource-poor areas represent the most vulnerable groups. Iron deficiency impairs the cognitive development of children from infancy through to adolescence. It damages immune mechanisms and is associated with increased morbidity rates. Iron deficiency commonly develops after six months of age if complementary foods do not provide sufficient absorbable iron, even for exclusively breastfed infants (World Health Organization [WHO] et al, 2001). The WHO recommends universal iron supplementation when prevalence of anaemia is more than $40 \%$ (WHO, 2004).

In the Eastern Mediterranean regions there is an endemic high prevalence of iron-deficiency anaemia (Verster, 1996) due to low total iron intake, low bioavailability (in many diets over $80 \%$ of iron is of non-haem origin) and high intake of inhibitors of iron absorption (unleavened bread and tea are severe inhibitors of iron absorption and are consumed in large amounts everywhere). Anaemia and stunting prevalence in Gaza have always been found to be very high in recent years (Abdeen, 2002; Rahim et al 2009).

\subsection{Emergency situation}

In the Gaza Strip the basic living conditions of all the inhabitants have deteriorated constantly in recent years, particularly after the "Cast Lead" operation in January 2009: the blockade and the closure of terminals for the movement of goods and people created a very tense situation which severely affected the wellbeing of all the inhabitants: $98 \%$ of private businesses closed and the unemployment rate increased to $48.8 \%$, while $80 \%$ of the population lives below the poverty line and $79 \%$ is aid-dependent. The rate of food insecure households in Gaza has also increased to $75 \%$, up from $56 \%$ before the Cast Lead operation. Furthermore, the growing inability of the population to consume iron-rich animal proteins and fresh fruit and vegetables, which contain the vitamins required for iron absorption, is bound to have a critical impact on the already high prevalence of mild and moderate iron 
deficiency anaemia in the Gaza Strip, habitually already about $20 \%$ higher than in the West Bank (WHO, 2009; World Bank, 2009).

The National Nutrition Surveillance System Report (PNA, MOH, 2010) has confirmed a worsening level of anaemia and chronic malnutrition in the Gaza Strip, with an overall anaemia prevalence of $76.2 \%$ (45.5\% in the West Bank) among children 9-12 months old and $58.6 \%$ (9.5\% in the West Bank) among school children. Stunting prevalence in school children was $7.9 \%$ in the Gaza Strip and $4.4 \%$ in the West Bank. The national survey does not provide any data for children between the ages of 12 months and 5 years.

\subsection{Present humanitarian intervention}

Terre des Hommes Italy ${ }^{1}$ (Tdh-It) and its Palestinian partner Palestinian Medical Relief Society $^{2}$ (PMRS) started operating with several humanitarian projects in Gaza in 2009, targeting pre-school children in a holistic way, where the prevention and treatment of anaemia have played a fundamental role. The projects were supported by the Italian Cooperation and other European donors.

It is worth pointing out that the Tdh-It and PMRS projects were designed and implemented as (and in the framework of) humanitarian interventions and not study; nevertheless, the projects have also been supported by a strong monitoring and evaluation system that has provided us with a massive and structured quantity of information allowing us to present the projects' impact and data as a case study, although the possibility of bias in the sample selections has to be borne in mind.

There is a strong need for a more evidence-based approach in humanitarian medical work and although a substantial body of knowledge has been accumulated regarding the effectiveness of interventions in acute emergencies, especially in refugee settings, the evidence base is much weaker for situations of protracted conflict with longer-term programmes in less controlled settings. (Banatvala and Zwi, 2000; Robertson et al, 2002; Roberts and Hofmann, 2004)

\section{Method}

\subsection{Nutritional health projects}

The interventions that Tdh-It and PMRS implemented included the following components:

- screening for IDA and malnutrition in 22 kindergartens (South Gaza: Rafah and Khan Younis Governorates) and 4 paediatric clinics (North Gaza: Northern Governorate);

- $\quad$ iron and vitamin supplementation based on therapeutic or preventive WHO protocols for all children contacted;

- medical follow-up for anaemic and malnourished children;

- provision of a home visit service for anaemic and malnourished children in order to:

- $\quad$ assess families' and children's nutritional habits (24-hour recall questionnaire)

\footnotetext{
1 Terre des Hommes Italia (Tdh-It) was founded in 1989 in Milan (Italy) and is part of the Terre des Hommes International Federation. It is a non-profit non-governmental organisation (ONLUS) whose mission it is to carry out humanitarian relief and international development projects for the benefit of children, their families and communities.

2 Palestinian Medical Relief Society (PMRS) is a grassroots, community- based Palestinian health organization founded in 1979. PMRS operates with 4 Primary Health Care Centres (PHCCs) in the Gaza Strip, providing preventive and curative services, and specialized health care for women and children.
} 
- $\quad$ provide family nutritional counselling

- support behavioural health change;

- health education sessions for mothers and fathers - held at the clinics, in kindergarten and during home visits.

Children who were still anaemic after intervention underwent further clinical investigation, treatment and longer follow-up.

The following table summarizes the activities and treatment protocols for the different projects.

\begin{tabular}{|c|c|c|c|c|}
\hline Period & Area & Target & Intervention for anaemics & Treatment for anaemics* \\
\hline $\begin{array}{c}\text { September } \\
2009 \text { - } \\
\text { June } 2010\end{array}$ & $\begin{array}{c}\text { South } \\
\text { Gaza } \\
(1)\end{array}$ & $\begin{array}{c}\text { Children in } \\
12 \text { kindergar- } \\
\text { tens and } \\
\text { their siblings }\end{array}$ & $\begin{array}{c}\text { Screening and treatment, } \\
\text { monthly follow-up with } \\
\text { haemoglobin control after } 4 \\
\text { months, health education, } \\
\text { home visit for anaemic } \\
\text { children }\end{array}$ & $\begin{array}{c}\text { Iron polymaltose } \\
\text { complex } 5 \mathrm{mg} / \mathrm{kg} \text { and } \\
\text { multivitamins daily for } 4 \\
\text { months, followed by } \\
\text { preventive iron (1mg/kg } \\
\text { daily) }\end{array}$ \\
\hline $\begin{array}{c}\text { January } 2010 \\
\text { December } \\
2010\end{array}$ & $\begin{array}{c}\text { North } \\
\text { Gaza }\end{array}$ & $\begin{array}{c}\text { Children } \\
\text { from } 3 \text { local } \\
\text { communities } \\
\text { invited to } \\
\text { local clinics }\end{array}$ & $\begin{array}{l}\text { Screening, treatment, follow- } \\
\text { up after } 3 \text { months with } \\
\text { haemoglobin test, health } \\
\text { education, home visit only for } \\
\text { some anaemic children }\end{array}$ & $\begin{array}{c}\text { Iron polymaltose } \\
\text { complex } 3-6 \mathrm{mg} / \mathrm{kg} \text { and } \\
\text { multivitamins daily for } \\
\text { at least } 3 \text { months, } \\
\text { followed by } \\
\text { multivitamin including } \\
\text { iron (1mg/ } \mathrm{kg} \text { daily) }\end{array}$ \\
\hline $\begin{array}{c}\text { September } \\
2010 \text { - } \\
\text { June } 2011\end{array}$ & $\begin{array}{c}\text { South } \\
\text { Gaza } \\
(2)\end{array}$ & $\begin{array}{c}\text { Children in } \\
11 \text { kindergar- } \\
\text { tens and } \\
\text { their siblings }\end{array}$ & $\begin{array}{c}\text { Screening and treatment, } \\
\text { monthly follow-up with } \\
\text { haemoglobin control after } 4 \\
\text { months, health education, } \\
\text { home visit for anaemic } \\
\text { children }\end{array}$ & $\begin{array}{c}\text { Iron polymaltose } \\
\text { complex } 5 \mathrm{mg} / \mathrm{kg} \text { and } \\
\text { multivitamins daily for } 4 \\
\text { months, followed by } \\
\text { preventive iron (1mg/kg } \\
\text { daily) }\end{array}$ \\
\hline
\end{tabular}

${ }^{*}$ A paediatrician or medical doctor changed the dosage and length of treatment when required by the child's clinical condition.

Table 1. Summary of Tdh-It/ PMRS nutritional projects in Gaza.

\subsection{Data collection}

Data were collected using two questionnaires, which were also used during the monitoring process:

1. CHILD FILE (annex-1): basic information about family and screened children gathered in the kindergarten during screening and follow-up visits. 10,445 children were screened for anaemia (blood test), including the main anthropometric indicators (height, weight), between October 2009 and March 2011: 3,941 (37.7\%) children were screened at 3 paediatric clinics in northern Gaza (Izbet Beit Hanoun, Umm El Nasser, Jabalia/Beit Lahia) while the other 6,504 were screened in the kindergartens (including siblings aged less than 6 years) in southern Gaza (eastern areas of Khan Younis and western areas of Rafah City). 


\section{FAMILY INFORMATION}

1) Name of the family's head (four names)

a. Name in Arabic

2) ID number of the family's head:

Family code _ I

3) Full Address:

4) Telephone $n$

5) Number of family's members:

below 5 years: __ ; $\quad 5-18$ years: _ _

6) Mother's personal status:

Married but living alone

Living with husband divorced Widow Married but living with her family Dead mother

7) Mother's education:

$$
\text { Preparatory }
$$

8) Father's education:

$$
\text { Preparatory }
$$

Illiterate can read \& write

secondary lower diploma

9) Father Job:
(1) Worker
(2) Government/Municipality employee
(3) Self employee
(4) Business (employing others)
(5) Peasant
(6) Shepherd
(7) Driver
(8) Unemployed
(9) Other

10) Mother age 11) n. of pregnancy

12) n. of deliveries

13) Pregnant now Yes Not

$\mathrm{N}^{\circ}$ of death children

\begin{tabular}{|l|l|l|}
\hline & $<1$ year & $1-5$ years \\
\hline$M$ & & \\
\hline$F$ & & \\
\hline
\end{tabular}

\section{CHILD FILE}

14) Date of visit_ _ _ _ _ Family code _ _ _ CODE of the Child _._

15) Name of the Child

16) Date of birth

17) ID number of the child:

18) attending KG Yes Not

19) Sex: $M \quad F$

20) Weight $(\mathrm{kg})_{-,-}$

21) Height (cm)

22) Percentile weight for age

23) $\mathrm{Hb}$ level _ _ _

24) Referred for doctor visit Yes Not

25) Referred to clinic Yes Not

Reason

$25 \mathrm{~b})$ does the child suffer from a chronic disease? Thalassaemia G6PD Other

26) Already receiving fortified food? Yes Not comments.

$27) \mathrm{N}^{\circ}$ of iron bottles given: _- $\left(\mathrm{ml} / \mathrm{day} \_\right.$__ $\left.\quad 28\right) \mathrm{N}^{\circ}$ of MULTIVITAMIN given:

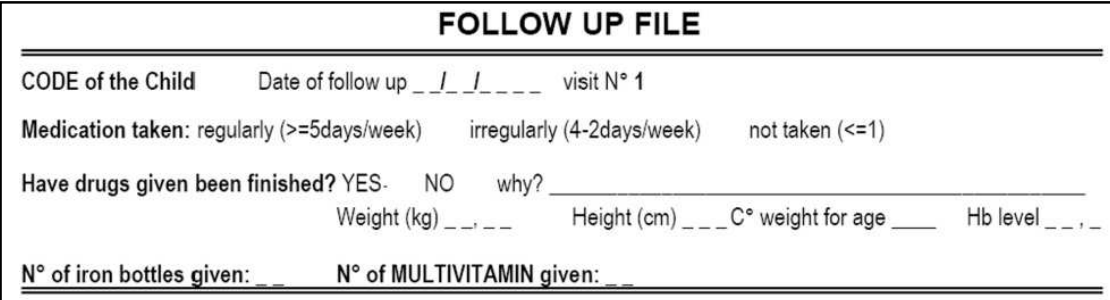

ANNEX 1. Extract from the CHILD FILE. 
2. HOME VISIT (annex-2): details of the families of anaemic children were collected twice during home visits (coinciding roughly with the start and end of treatment) and concerned mother's knowledge, nutritional habits of all the children, iron treatment compliance and adoption of healthy life styles.

In the project implemented in northern Gaza only some families received home visits and there was also a problem with coding of the children, so the link between data collected during screening and the home visit was not available; for this reason we analysed only data from the kindergarten visits carried out in southern Gaza. A total of 1,733 families of anaemic children screened in kindergartens were visited at home.

\begin{tabular}{|c|c|c|c|c|c|c|c|c|c|}
\hline \multicolumn{9}{|c|}{$\begin{array}{l}\text { NUTRITIONAL QUESTIONNAIRE } \\
\text { Is the child presently breastfed? }\end{array}$} & \\
\hline Child 1 & \multicolumn{3}{|c|}{ Child 2 } & \multicolumn{2}{|r|}{ Child 3} & \multicolumn{3}{|c|}{ Child 4} & \\
\hline $\begin{array}{l}\text { Yes No } \\
\text { if yes no. of } \\
\text { times. }\end{array}$ & \multicolumn{3}{|c|}{$\begin{array}{l}\text { Yes No } \\
\text { if yes no. } \\
\text { of times }\end{array}$} & \multicolumn{2}{|c|}{$\begin{array}{l}\text { Yes No } \\
\text { if yes no. } \\
\text { of times. }\end{array}$} & $\begin{array}{l}\text { Yes } \\
\text { if yes } n \\
\text { of time }\end{array}$ & No & & \\
\hline \multirow{2}{*}{\multicolumn{6}{|c|}{ How many meals the child has on average per day? }} & \multirow{2}{*}{\multicolumn{3}{|c|}{$\begin{array}{l}\text { Child } 1 \_ \text {Child } 2 \\
\text { Child } 3 \_ \text {Child } 3\end{array}$}} & \multirow{2}{*}{ 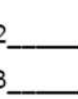 } \\
\hline & & & & & & & & & \\
\hline & \begin{tabular}{c|c} 
Child \\
1
\end{tabular} & \begin{tabular}{c|c|c|c|} 
Child \\
2
\end{tabular} & \begin{tabular}{c|c} 
Child \\
3
\end{tabular} & \begin{tabular}{c|c} 
Child \\
4
\end{tabular} & & \begin{tabular}{c|c|c} 
Child \\
1
\end{tabular} & \begin{tabular}{c|c|} 
Child \\
2
\end{tabular} & \begin{tabular}{c|c|c|c|} 
Child \\
3
\end{tabular} & $\begin{array}{c}\text { Child } \\
4\end{array}$ \\
\hline \multicolumn{10}{|c|}{$\begin{array}{l}\text { Indicate number of "portion" of the following food (or number of items where indicated) that the CHILD } \\
\text { has eaten in the last } 24 \mathrm{~h} \text { ? (One portion is big as the person's fist) }\end{array}$} \\
\hline Vegetables & & & & & $\begin{array}{l}\text { Cheese and } \\
\text { dairy products }\end{array}$ & & & & \\
\hline Fruits & & & & & Bread & & & & \\
\hline Legumes & & & & & Rice & & & & \\
\hline Nuts and Seeds & & & & & Pasta & & & & \\
\hline Meat & & & & & Potatoes & & & & \\
\hline Chicken & & & & & Biscuits/cake & & & & \\
\hline Fish & & & & & $\begin{array}{l}\text { Chocolate } \\
\text { bars (n.) }\end{array}$ & & & & \\
\hline Eggs (n.) & & & & & $\begin{array}{l}\text { Sweets and } \\
\text { candies }(n)\end{array}$ & & & & \\
\hline $\begin{array}{l}\text { Chips (n. of } \\
\text { sachet) }\end{array}$ & & & & & $\begin{array}{l}\text { Jam/ cream } \\
\text { (n. of big spoon) }\end{array}$ & & & & \\
\hline \multicolumn{10}{|c|}{$\begin{array}{l}\text { Indicates how many cups/glasses the CHILD had of the following drinks in the last } 24 \mathrm{~h} \text { ? } \\
\text { (mark with X) }\end{array}$} \\
\hline Milk (with sugar) & & & & & $\begin{array}{l}\text { Tea (outside } \\
\text { meal) }\end{array}$ & & & & \\
\hline $\begin{array}{l}\text { Milk (without } \\
\text { sugar) }\end{array}$ & & & & & $\begin{array}{l}\text { Tea (with main } \\
\text { meal) }\end{array}$ & & & & \\
\hline Water & & & & & Fresh Juice & & & & \\
\hline Soft drink & & & & & Packed Juice & & & & \\
\hline
\end{tabular}


KNOWLEDGE OF THE MOTHER ASSESSMENT (don't prompt the mother before she has finished to answer the all questions)

- Why anaemia is bad for the child? Doesn't know infection vulnerability ; poor school performance ; mental retard ; other answers AHA weakness

- What are the causes of anaemia is bad for the child? Doesn't know__ Tea with meal___; lack of meat/chicken /fish ___, lack of rich iron vegetable (she can mention one) ; some diseases ; poverty other answers

- What can be done to prevent or treat anaemia? Doesn't know good diet ; iron supplementation food fortification wrong answer Breast feeding

- What is the GOOD food for the child growth? doesn't know Vegetables__ Legumes Cheese and milk products ; Fruits ; fresh juice Meat _ Chicken Fish Eggs Milk

- What are the food BAD for the child growth? Chips__; Salted biscuits__; Butter__; Biscuits and candies ; ice cream jam and cream

\section{doesn't know - Sugar ; Soft drinks} Chocolate bars Sweets Cakes other answers

ANNEX 2. Extract from the HOME VIST FILE (nutritional questionnaire and mother's knowledge assessment).

Data were collected for 3,619 children (2,024 anaemics and 1,595 non-anaemic siblings) of these families concerning:

- drug adherence, tolerance, storage and administration

- mother's knowledge of anaemia and nutrition

- $\quad$ nutritional habit (24-hour recall nutritional questionnaire)

The second visit took place on average 111 days $(S D=46)$ after the first visit.

The home visit data included children on iron preventive treatment, not only anaemics.

\subsection{Haemoglobin assessment}

Blood samples taken at kindergarten were analysed using the Haemocue rapid test.

Blood samples in clinics were tested using an aXE-2100D automated haematology analyser (Sysmex).

\subsection{Definition of anaemia and malnutrition}

Anaemia. Children with a haemoglobin level below 11g/dl were considered anaemic. Anaemia was defined as mild for a haemoglobin level of 10-11g/dl, moderate for 7-9.9 $\mathrm{gm} / \mathrm{dl}$ and severe for less than $7 \mathrm{gm} / \mathrm{dl}$.

Malnutrition. The software used to calculate Z score was "WHO ANTHRO, Software for Calculating Anthropometry, Version 2.0" and "WHO ANTHROPLUS". Segments of the population below $-2 \mathrm{Z}$ score (2SD) were considered as suffering from wasting (acute malnutrition, weight/height), underweight (weight/age) and stunting (chronic malnutrition, height/age). Segments of the population above $2 \mathrm{Z}$ of body mass index for age were considered as overweight (WHO, 2009). 


\subsection{Statistical analyses}

Statistical analyses were performed using STATA software (Stata Statistical Software release 9.2, 2007; Stata Corporation, College Station, Texas). Uni- and multivariate binary regression and chi square test were used where appropriate. All statistical tests were two sided, and P values of $<0.05$ were considered significant.

\subsection{Main objectives}

As already mentioned, the intervention was not conceived or performed as a study, thus the monitoring and evaluation (M\&E) system was a tool for correct activity management and for evaluating the impact of the project, but it did allowed us to gather useful information:

- $\quad$ for comparing the prevalence of anaemia and malnutrition before and after the project in the pre-school child population;

- for identifying risk factors for anaemia;

- for assessing compliance and tolerability of treatment and their association with lack of improvement;

- for assessing change in the families' knowledge of anaemia and nutrition (mothers);

- for assessing nutritional habits and evaluating changes promoted by intervention;

- for evaluating anaemia prevalence 1 year after intervention (long-lasting impact);

- for monitoring and evaluating anaemic children who did not improve during the first phase of the project, including identification of non-iron deficiency anaemia (e.g. thalassaemia).

\subsection{Ethical approval}

The Helsinki Committee of Palestinian Ministry of Health gave approval for publication of present paper.

\section{RESULTS}

\subsection{Anaemia prevalence at screening}

10,445 children were screened for anaemia between October 2009 and March 2011: 3,941 $(37.7 \%)$ of them were screened at the PMRS paediatric clinics in northern Gaza, while the other 6,504 (including siblings) were screened at the 22 kindergartens in southern Gaza.

$51.6 \%(5,391)$ of the screened children were male. The mean age of the screened children was 39.7 months $(\mathrm{SD}=18.0)$, with no difference between the sexes.

$5.877(56.3 \%)$ of the tested children were not anaemic and 4,568 (43.7\%) were anaemic (HB level $<11 \mathrm{~g} / \mathrm{dl}) ; 421$ of the anaemics $(4.1 \%)$ had a haemoglobin level below $9 \mathrm{~g} / \mathrm{dl}$.

The prevalence of anaemia was similar in males $(44.0 \%)$ and females $(43.4 \%, p=0.5)$ and strongly and inversely associated with age, as shown in Figure 1 and Table 1: anaemia had a very high prevalence in children below 24 months, peaking at 6-11 months (76.2\%) and 1223 months $(72.2 \%)$. The percentage was much lower in older children $(17.0 \%$ for children $>$ 5 years old).

When considering only the under-5 population, the prevalence of anaemia was $49 \%$ $(4,271 / 8,709)$, but it should be noted that children below 12 months of age were underrepresented and our sample did not adequately represent the under-5 population of Gaza. 


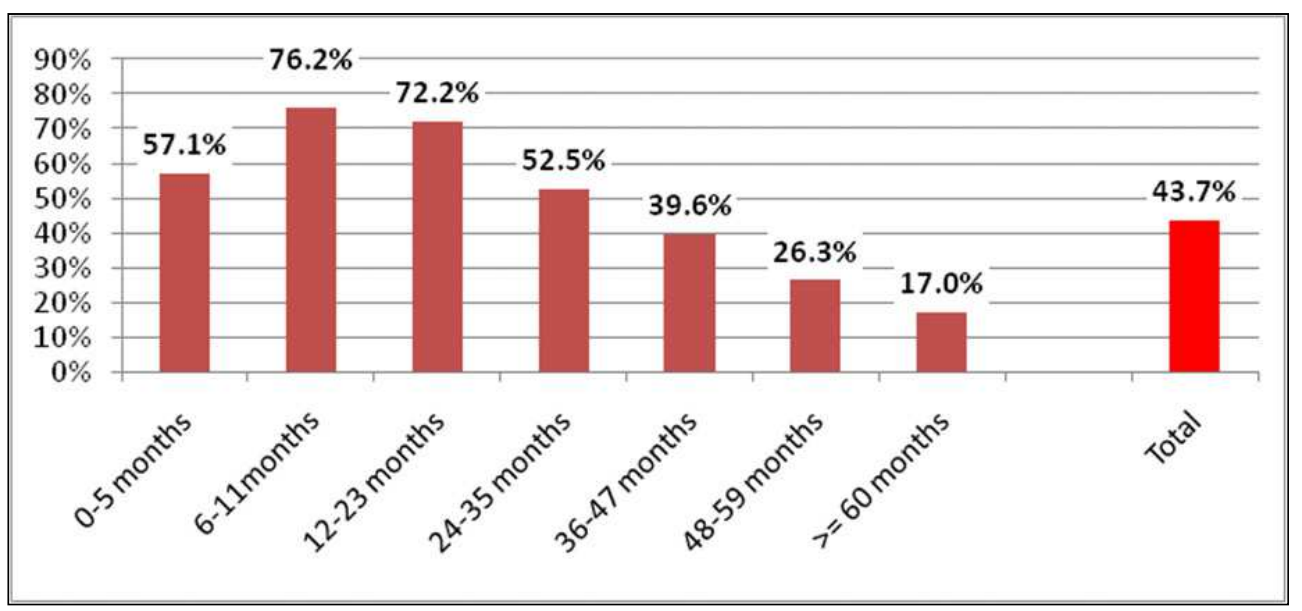

Fig. 1. Prevalence of anaemia by age group.

\begin{tabular}{|c|c|c|c|c|c|c|c|}
\hline $\begin{array}{c}\text { Age } \\
\text { groups }\end{array}$ & $\begin{array}{c}\mathrm{N}^{\circ} \text { of } \\
\text { screened }\end{array}$ & $\begin{array}{c}\mathrm{N}^{\circ} \text { of } \\
\text { anaemics }\end{array}$ & $\begin{array}{c}\% \text { of } \\
\text { anaemics }\end{array}$ & $\begin{array}{c}\% \text { of } \\
\text { stunting }\end{array}$ & $\begin{array}{c}\% \text { of } \\
\text { underweight }\end{array}$ & $\begin{array}{c}\% \text { of } \\
\text { wasting }\end{array}$ & $\begin{array}{c}\% \text { of } \\
\text { overweight }\end{array}$ \\
\hline $\begin{array}{c}0-5 \\
\text { months }\end{array}$ & 56 & 32 & $57.1 \%$ & $0.0 \%$ & $3.6 \%$ & $8.9 \%$ & $5.4 \%$ \\
\hline $\begin{array}{c}\text { months } \\
\text { m-23 } \\
\text { months }\end{array}$ & 2,026 & 1,462 & $72.2 \%$ & $10.7 \%$ & $2.9 \%$ & $2.9 \%$ & $7.2 \%$ \\
\hline $\begin{array}{c}24-35 \\
\text { months }\end{array}$ & 1,973 & 1,036 & $52.5 \%$ & $10.8 \%$ & $2.2 \%$ & $3.6 \%$ & $8.2 \%$ \\
\hline $\begin{array}{c}36-47 \\
\text { months }\end{array}$ & 1,967 & 778 & $39.6 \%$ & $9.6 \%$ & $2.5 \%$ & $3.2 \%$ & $6.3 \%$ \\
\hline $\begin{array}{c}48-59 \\
\text { months }\end{array}$ & 2,174 & 572 & $26.3 \%$ & $6.6 \%$ & $2.6 \%$ & $2.7 \%$ & $5.3 \%$ \\
\hline $\begin{array}{c}\geq 60 \\
\text { months }\end{array}$ & 1,726 & 294 & $17.0 \%$ & $6.2 \%$ & $2.1 \%$ & $1.8 \%$ & $3.8 \%$ \\
\hline \begin{tabular}{c} 
Total \\
\hline
\end{tabular} & 10,435 & 4,565 & $43.7 \%$ & $8.7 \%$ & $2.5 \%$ & $3.1 \%$ & $6.2 \%$ \\
\hline
\end{tabular}

Table 2. Prevalence of anaemia and malnutrition by age group. 
As shown in Table 3, anaemia was also associated with:

- $\quad$ mother's poor education, regardless of child's age $(p<0.0001)$

- $\quad$ stunting in children over 24 months of age

- not having received fortified food (data collected for kindergarten children only).

\begin{tabular}{|c|c|c|c|}
\hline & & $\begin{array}{l}\text { Children below } 24 \\
\text { months }(2,595)\end{array}$ & $\begin{array}{c}\text { Children over } 24 \\
\text { months }(7,850)\end{array}$ \\
\hline \multirow{4}{*}{ Mother's education } & No education (278) & $88 \%$ & $54 \%$ \\
\hline & Primary $(1,380)$ & $82 \%$ & $49 \%$ \\
\hline & High school $(5,887)$ & $71 \%$ & $31 \%$ \\
\hline & University $(2,423)$ & $69 \%$ & $30 \%$ \\
\hline \multirow{2}{*}{ Stunting } & No $(9,495)$ & $73 \%$ & $33 \%$ \\
\hline & Yes (901) & $73 \%$ & $45 \%$ \\
\hline \multirow{2}{*}{$\begin{array}{l}\text { Received fortified food } \\
\text { (only children screened at } \\
\text { kindergarten) }\end{array}$} & No $(2,172)$ & $73 \%$ & $30 \%$ \\
\hline & Yes $(4,312)$ & $60 \%$ & $24 \%$ \\
\hline
\end{tabular}

Table 3. Anaemia prevalence by age group and other variables.

A multivariate logistic analysis showed that being anaemic was associated with:

- child's younger age (odds ratio=0.95 for every month of age, $\mathrm{p}<0.0001$ )

- mother's education (OR=0.73 for each level, $\mathrm{p}<0.0001)$

- $\quad$ stunting $(\mathrm{OR}=1.36, \mathrm{p}<0.0001)$

- $\quad$ not having received fortified food $(\mathrm{OR}=1.35, \mathrm{p}<0.0001)$.

No association was found between anaemia and: mother's age, number of pregnancies, father unemployment or sex of the child.

Prevalence of underweight and wasting (acute malnutrition) were low (around 2-3\%), similar to the level registered in the normal healthy population according to WHO standards; prevalence of stunting was high $(8.7 \%)$, and overweight was moderately higher $(6.2 \%)$ than in the healthy population.

\subsection{Anaemia improvement after intervention}

4,077 of the anaemic children were monitored until a second haemoglobin test was performed, on average after 175 days $(S D=43)$ of treatment. Table 4 below shows that:

- of 4,077 children anaemic at enrolment 2,690 (66.0\%) were no longer anaemic and 1,387 (34.0\%) were still anaemic after 4-6 months of treatment;

- $\quad$ severe and moderate anaemia was reduced from $9.4 \%$ to only $1.7 \%$;

- of the 1,387 children still anaemic 360 (26.0\%) had an improvement in haemoglobin $\geq 1 \mathrm{~g} / \mathrm{dl}$, a clinically significant result, bringing to $74.8 \%$ the percentage of anaemic children with improved status;

- $\quad$ the mean haemoglobin level increased from $9.99 \mathrm{~g} / \mathrm{dl}$ to $11.0 \mathrm{~g} / \mathrm{dl}$. 


\begin{tabular}{|c|c|c|c|c|c|}
\hline Type of anaemia & \multicolumn{2}{|c|}{$\begin{array}{l}\text { Admission } \\
\text { n. } \%\end{array}$} & \multicolumn{2}{|c|}{$\begin{array}{l}\text { Last follow-up } \\
\text { n. } \%\end{array}$} & p value \\
\hline Severe and moderate anaemia $<9 g$ & 383 & $9.4 \%$ & 71 & $1.7 \%$ & \multirow{3}{*}{$<0.0001$} \\
\hline Mild anaemia & 3,694 & $90.6 \%$ & 1,316 & $32.3 \%$ & \\
\hline No anaemia & 0 & & 2,690 & $66.0 \%$ & \\
\hline $\begin{array}{l}\text { Mean haemoglobin level among } \\
1,211\end{array}$ & \multicolumn{2}{|c|}{$9.99 \mathrm{~g} / \mathrm{dl}$} & \multicolumn{2}{|c|}{$11.09 \mathrm{~g} / \mathrm{dl}$} & $<0.0001$ \\
\hline
\end{tabular}

Table 4. Anaemia status before and after treatment.

Anaemic children at screening were classified as "improved" if they recovered from anaemia or if they had at least a $>1 \mathrm{~g} / \mathrm{dl}$ increase in haemoglobin level. A strong link between improvement and child age was noticed: improvement was much lower for younger children (less than 60\%) compared to older ones (around 80\%), as shown in Figure 2 .

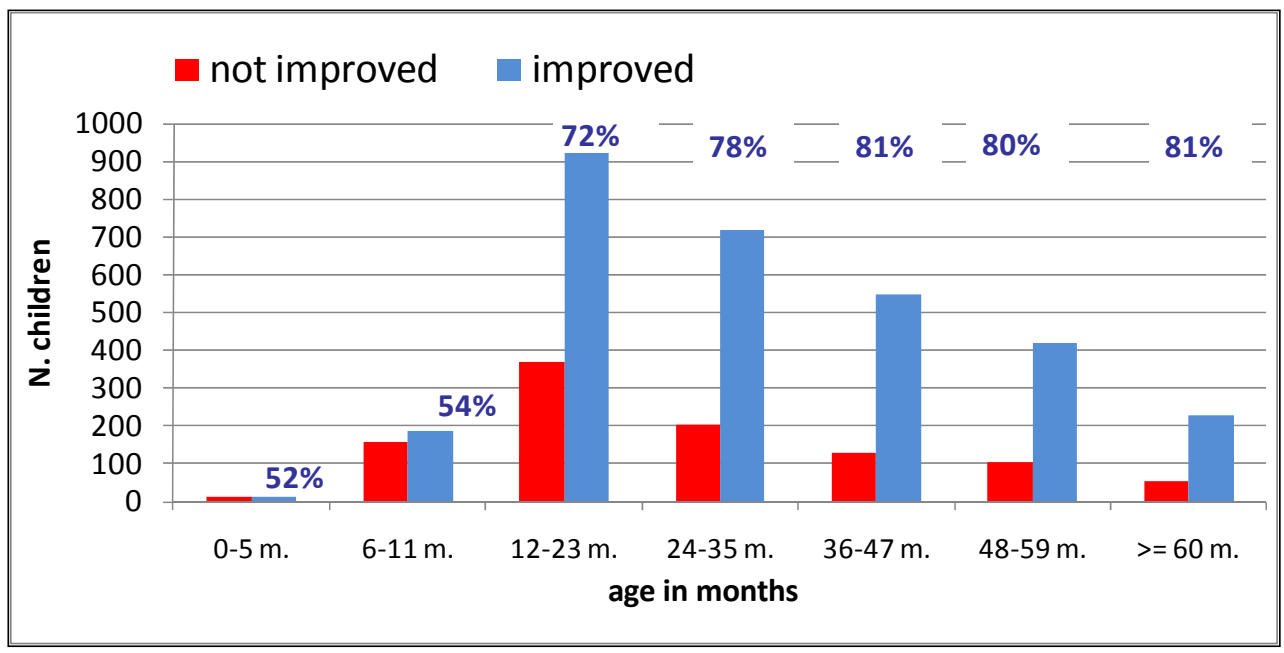

Fig. 2. Anaemia improvement after treatment by age group (number of children and $\%$ of improved).

Improvement was not associated with mother's education or other family variables collected.

In order to investigate the reasons for not improving we linked data collected via the CHILD FILE and HOME VISIT file to establish whether improvement was associated with:

- drug adherence

- drug tolerance

- $\quad$ mother's level of knowledge

- $\quad$ change in nutritional habits.

The above information was not available for all the children enrolled and is presented in detail in the following subsections (3.3 to 3.6). 


\subsection{Adherence to iron supplementation}

In the first two phases of the project (South Gaza-1 and North Gaza) we were unable to associate improvement with good adherence to iron supplementation; this was due to the fact that almost all the mothers reported having given the iron as prescribed. A more careful investigation in a subsample of still anaemic children showed that in order to obtain more reliable answers:

- the questions on adherence had to be more precise and more specific

- the investigator was not to blame the mothers.

For this reason a more precise and more sensitive data collection method was introduced in SOUTH GAZA-2; therefore, with regard to drug adherence, we present data limited to this project. Information on drug adherence was collected for all the 2,804 children enrolled, during each distribution at the kindergarten and during the home visit. Specific questions were asked, such as whether the drugs had been taken regularly ( $>5$ days/week), irregularly (4-2 days/week) or not at all $(\leq 1$ /week) during the previous week. Figure 3 below shows that:

- drugs were taken regularly by $57 \%$ of the children after one month, the percentage decreasing constantly to $45.7 \%$;

- the percentage of children who took drugs irregularly rose with time from $21.7 \%$ to $32.8 \%$;

- the percentage of children not taking drugs or not showing for follow-up increased with time.

The major reason mentioned for not taking drugs regularly were careless mother and/or child's refusal.

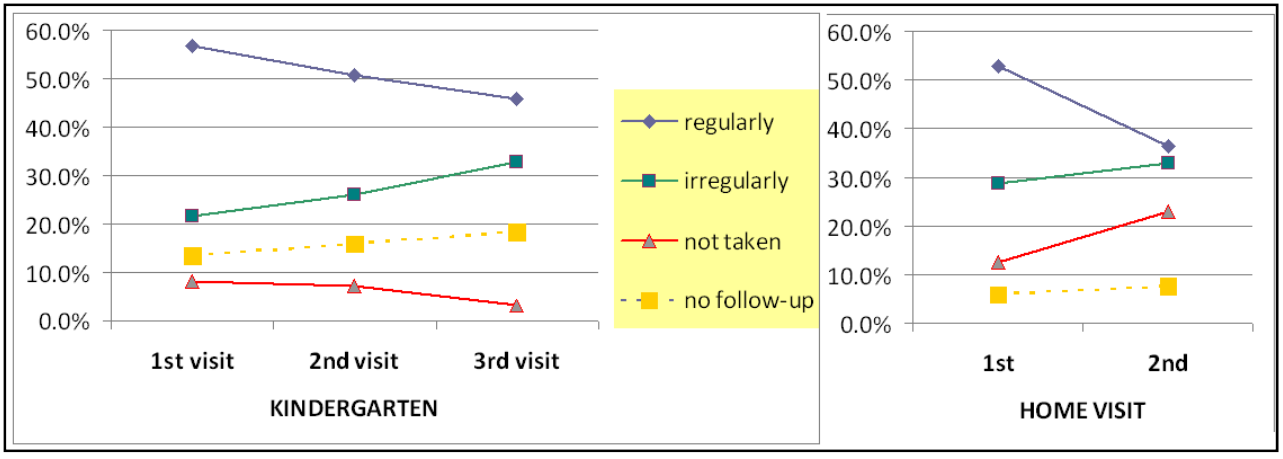

Fig. 3. Reported adherence among anaemic children.

To allow a better comparison we created a comprehensive index of drug adherence by combining all assessments performed, giving a score of 2 when the drugs were taken regularly, 1 when taken irregularly and 0 when not taken or the follow-up was missed. As shown in Table 5, there were 136 children who always took the drugs regularly, (score $=10$ ) and 31 who never took the medicine. We can further classify in 3 categories the level of adherence 


\begin{tabular}{|c|r|r|r|r|}
\hline Adherence category & \multicolumn{1}{l|}{ Adherence score } & \multicolumn{1}{l|}{ No. } & \multicolumn{1}{l|}{$\%$} & Cumulative $\%$ \\
\hline \multirow{4}{*}{ POOR } & 0 & 31 & $3.6 \%$ & $3.6 \%$ \\
\cline { 2 - 5 } & 1 & 35 & $4.1 \%$ & $7.7 \%$ \\
\cline { 2 - 5 } & 2 & 49 & $5.7 \%$ & $13.5 \%$ \\
\cline { 2 - 5 } & 3 & 39 & $4.6 \%$ & $18.1 \%$ \\
\cline { 2 - 5 } & 4 & 72 & $8.4 \%$ & $26.5 \%$ \\
\hline \multirow{3}{*}{ FAIR } & 5 & 77 & $9.0 \%$ & $35.5 \%$ \\
\cline { 2 - 5 } & 6 & 99 & $11.6 \%$ & $47.1 \%$ \\
\cline { 2 - 5 } & 7 & 93 & $10.9 \%$ & $58.0 \%$ \\
\hline \multirow{3}{*}{ GOOD } & 8 & 116 & $13.6 \%$ & $71.6 \%$ \\
\cline { 2 - 5 } & 9 & 106 & $12.4 \%$ & $84.1 \%$ \\
\cline { 2 - 5 } & 10 & 136 & $15.9 \%$ & $100.0 \%$ \\
\hline
\end{tabular}

Table 5. Adherence scores for anaemic children.

We found a significant association $(p<0.0001)$ between improvement of anaemia and the treatment adherence score (as previously described). The percentage of improvement after adjustment for age was:

- $\quad 68.0 \%$ for children with good adherence (score 8-10)

- $\quad 64.2 \%$ for children with fair adherence (score 5-7)

- $60.5 \%$ for children with poor adherence (score <5)

\subsection{Drug tolerance, storage and administration}

In the previous subsection we presented data on drug adherence recorded for anaemic children; the data here include non-anaemic children undergoing preventive treatment (prophylaxis).

There were very few reported complaints related to drug intake: around $2 \%$ in children with anaemia who received a higher dosage of iron and less than $1 \%$ for children on preventive treatment.

Vomiting and diarrhoea were the most common symptoms reported.

Drug storage was adequate in more than $90 \%$ of the cases during the first visit, the figure dropping slightly declined at the second visit. A similar pattern was noticed with regard to correct drug administration.

\begin{tabular}{|c|c|r|r|}
\hline & & \multicolumn{1}{|c|}{ 1st visit } & \multicolumn{2}{|c|}{ 2nd visit } \\
\hline \multirow{2}{*}{$\begin{array}{c}\text { Drug-related } \\
\text { complaints }\end{array}$} & anaemics & $1.8 \%$ (38 cases) & $1.8 \%$ (37 cases) \\
\cline { 2 - 4 } & non-anaemics & $0.7 \%$ (11 cases) & $0.4 \%$ (7 cases) \\
\hline & & & $93.08 \%$ \\
\hline \multirow{2}{*}{$\begin{array}{c}\text { Adequate drug } \\
\text { storage }\end{array}$} & anaemics & $94.32 \%$ & $89.33 \%$ \\
\cline { 2 - 4 } & non-anaemics & $92.75 \%$ & $87.54 \%$ \\
\hline \multirow{2}{*}{$\begin{array}{c}\text { Correct drug } \\
\text { administration }\end{array}$} & anaemics & $89.65 \%$ & $81.89 \%$ \\
\cline { 2 - 4 } & non-anaemics & $86.26 \%$ & \\
\hline
\end{tabular}

Table 6. Drug tolerance, storage and administration among anaemic and non-anaemic children. 


\subsection{Mother's knowledge of anaemia and nutrition}

A total of 1,724 mothers answered a questionnaire on anaemia and nutrition (annex-2) twice during the two home visits. The questions were open-ended and the social workers did not prompt any answers to them.

Considering the average number of good/correct answers given by mothers, it is clear for each section that there was a significant increase in knowledge ( $\mathrm{p}$-value paired $\mathrm{t}$-test was always $<0.0001)$.

The average number of good answers increased by $35 \%$, from 7.7 to 10.4 . The number of mothers improving their score was 1,205 (70\%), while 247 showed the same and 272 a lower score.

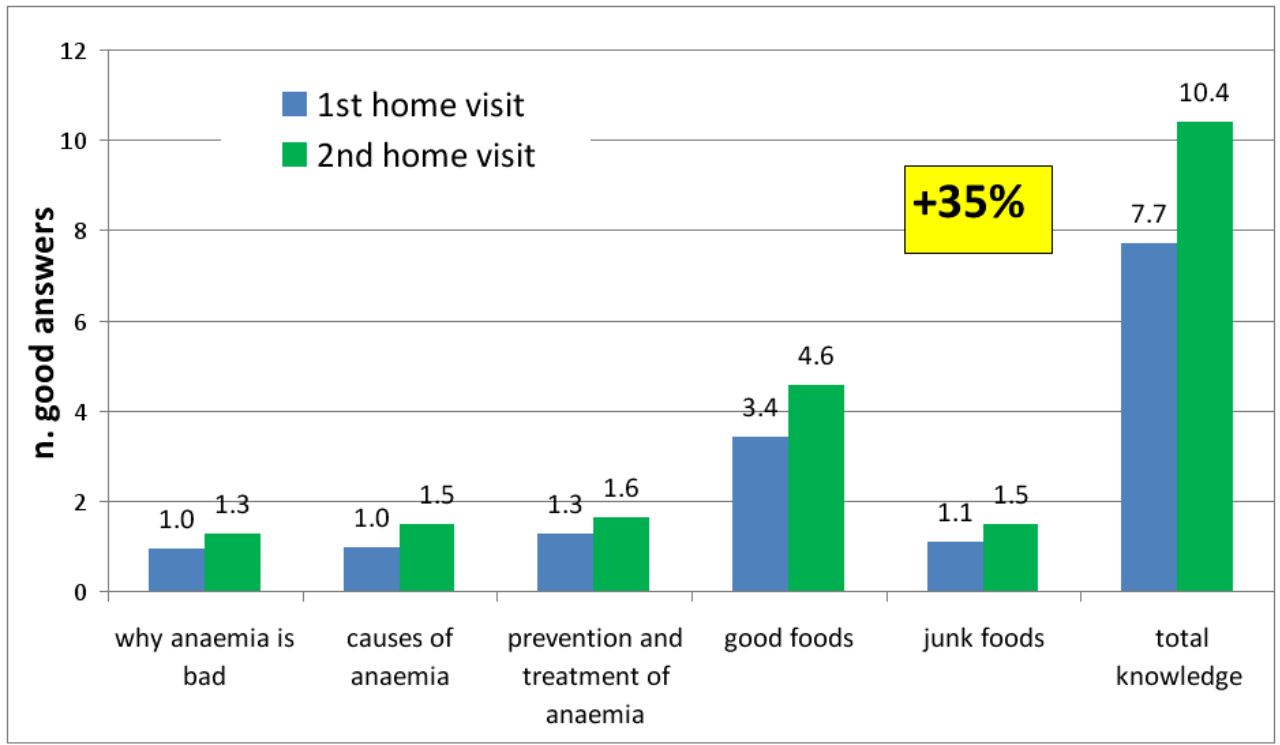

Fig. 4. Mother's knowledge of anaemia and nutrition at the first and second home visit.

When we considered as having a "good basic knowledge" women with a score of $\geq 10$ with at least one good answer for every section, we found that the percentage of mothers with a good basic knowledge was only $20.2 \%$ at the first home visit, rising to $51.6 \%$ at the second home visit $(\mathrm{p}<0.0001)$.

The level of "good basic knowledge" was strongly related to mother's education at the first home visit, ranging from $10 \%$ in women with primary education to $28 \%$ for the highly educated $(p>0.0001)$. At the second visit no difference in good basic nutritional knowledge was seen between mothers with different standards of education (apart from the 12 illiterate subjects).

This is particularly important since:

- less educated mothers displayed a proportionally higher increase in knowledge than highly educated ones;

- disparity was reduced at the end of the project;

- we proved that the nutritional messages given were well understood even by the less advantaged, who are more in need, 


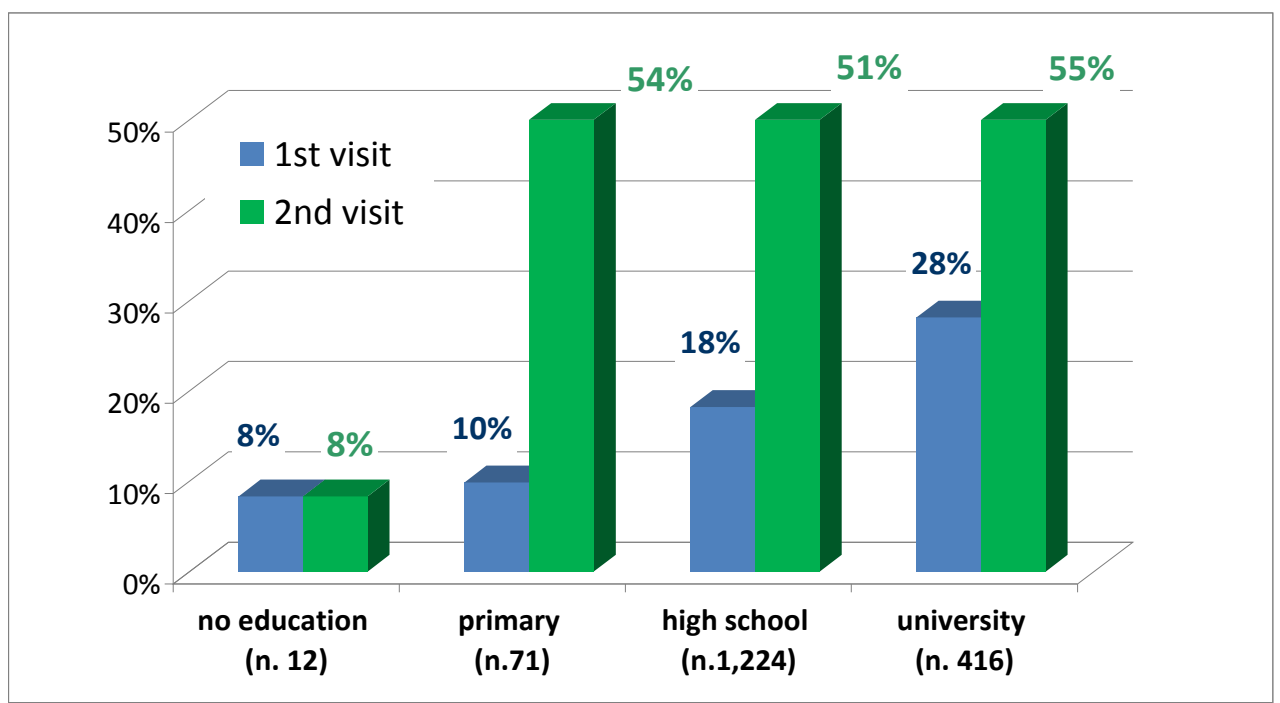

Fig. 5. Good-basic knowledge at the first and second home visit by mother's education level.

We found an association between improvement in anaemic status and mother's good basic knowledge at the second home visit: after adjustment for child's age, mothers with a good-basic knowledge were $24 \%$ more likely to have a child with improved status than mothers without a good basic knowledge (odds ratio=1.24, $p=0.013$ ).

Furthermore, in a sub-sample of children with available data, we found a significant association $(p=0.016)$ between improvement of anaemia with mothers' and fathers' participation in awareness sessions at the kindergarten. The percentages of improvement stratified for participation were:

- $78.3 \%$ for the 69 children whose mother and father both participated in the awareness session

- $\quad 69.1 \%$ for the 162 children whose mother participated in the awareness session

- $62.3 \%$ for the 533 children whose parents did not participate in the awareness session.

\subsection{Change in children's nutritional habits}

In order to appreciate a possible impact in nutritional habit we compared the results of the 24-hour recall nutritional survey done during the first home visit with those of the same survey repeated 3-4 months later.

Since children below 2 years of age, who are at the weaning stage, can have a substantial change in their nutritional habit independently of the project, we analysed in a stratified way the results for children below 24 months of age (where considerable change is naturally expected) and those for older children (where changes can reflect project impact).

The specific messages of nutritional counselling were:

- $\quad$ stop tea consumption during meals;

- increase vegetable and fruit consumption;

- increase haem-rich animal food consumption (meat, fish, chicken);

- reduce junk food consumption. 


\subsubsection{Children over $\mathbf{2 4}$ months of age at screening}

The overwhelming majority of children were having an average of 3 meals a day before and after the project.

When considering the average number of portions consumed the previous day, we noticed a $25 \%$ increase in the consumption of fruit and vegetables, $+29 \%$ for staple food, $+19 \%$ for animal products and $+25 \%$ for haem-rich animal food.

\begin{tabular}{|c|c|c|c|c|c|}
\hline \multirow[t]{2}{*}{ Table 7a } & & \multicolumn{4}{|c|}{ Anaemic children $\geq 24$ months } \\
\hline & & 1st visit & 2nd visit & change & $\begin{array}{l}\mathrm{p} \text { value } \\
\text { paired } \mathrm{t} \text {-test }\end{array}$ \\
\hline \multicolumn{2}{|c|}{ Number of children } & \multicolumn{2}{|l|}{1,251} & & \\
\hline \multicolumn{2}{|c|}{ Average no. of meals } & 2.93 & 2.96 & & \\
\hline \multicolumn{2}{|c|}{$\%$ of children having fewer than 3 meals } & $10.27 \%$ & $6.59 \%$ & $-36 \%$ & 0.0001 \\
\hline \multirow{8}{*}{ 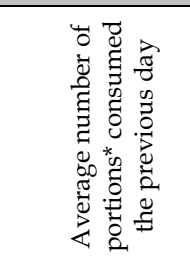 } & Vegetables, fruits and legumes & 2.26 & 2.83 & $25 \%$ & $<0.0001$ \\
\hline & Staple food & 2.11 & 2.73 & $29 \%$ & $<0.0001$ \\
\hline & Animal foods & 2.42 & 2.88 & $19 \%$ & $<0.0001$ \\
\hline & Of which haem-rich food & 0.56 & 0.71 & $25 \%$ & $<0.0001$ \\
\hline & Junk food & 2.24 & 2.01 & $-10 \%$ & $<0.0001$ \\
\hline & Of which chips & 0.82 & 0.57 & $-30 \%$ & $<0.0001$ \\
\hline & Of which candies & 0.21 & 0.24 & $18 \%$ & 0.03 \\
\hline & Of which soft drinks & 0.11 & 0.08 & $-28 \%$ & 0.026 \\
\hline \multicolumn{2}{|c|}{ Average number of times child eats junk food between meals } & 2.04 & 1.93 & $-6 \%$ & 0.0001 \\
\hline \multirow{4}{*}{ 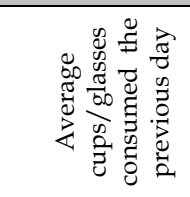 } & Water & 4.17 & 5.07 & $22 \%$ & $<0.0001$ \\
\hline & $\begin{array}{r}\text { No. of cups } \\
\text { (Percentage drinking tea) }\end{array}$ & $\begin{array}{l}1.18 \\
(67 \%)\end{array}$ & $\begin{array}{l}0.76 \\
(54 \%)\end{array}$ & $\begin{array}{l}-35 \% \\
-19 \%\end{array}$ & $\begin{array}{l}<0.0001 \\
<0.0001\end{array}$ \\
\hline & Of which tea outside meals & 0.90 & 0.61 & $-33 \%$ & $<0.0001$ \\
\hline & Of which tea with meals & \begin{tabular}{|l|}
0.28 \\
$(16.3 \%)$
\end{tabular} & $\begin{array}{l}0.15 \\
(10.6 \%)\end{array}$ & $\begin{array}{l}-45 \% \\
-35 \% \\
\end{array}$ & $\begin{array}{l}<0.0001 \\
<0.0001\end{array}$ \\
\hline \multirow[t]{2}{*}{ Table 7b } & & \multicolumn{4}{|c|}{ Non-anaemic children $\geq 24$ months } \\
\hline & & 1st visit & 2nd visit & change & $\begin{array}{l}\mathrm{p} \text { value } \\
\text { paired t-test }\end{array}$ \\
\hline \multicolumn{2}{|c|}{ Number of children } & \multicolumn{2}{|l|}{1451} & & \\
\hline \multicolumn{2}{|c|}{ Average no. of meals } & 2.95 & 2.99 & & \\
\hline \multicolumn{2}{|c|}{$\%$ of children having fewer than 3 meals } & $6.72 \%$ & $4.56 \%$ & $-32 \%$ & \\
\hline \multirow{8}{*}{ 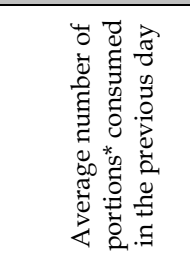 } & Vegetables, fruit and legumes & 2.26 & 2.77 & $23 \%$ & $<0.0001$ \\
\hline & Staple food & 2.21 & 2.79 & $26 \%$ & $<0.0001$ \\
\hline & Animal foods & 2.44 & 2.89 & $19 \%$ & $<0.0001$ \\
\hline & Of which haem-rich food & 0.58 & 0.69 & $19 \%$ & $<0.0001$ \\
\hline & Junk food & 2.26 & 2.12 & $-6 \%$ & 0.003 \\
\hline & Of which chips & 0.87 & 0.63 & $-27 \%$ & $<0.0001$ \\
\hline & Of which candies & 0.21 & 0.29 & $37 \%$ & $<0.0001$ \\
\hline & Of which soft drinks & 0.10 & 0.11 & $16 \%$ & 0.13 \\
\hline \multicolumn{2}{|c|}{ Average number of times child eats junk food between meals } & 2.04 & 2.01 & $2 \%$ & $-3 \%$ \\
\hline \multirow{4}{*}{ 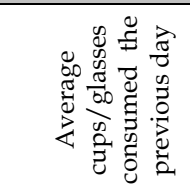 } & Water & 4.53 & 5.30 & $17 \%$ & $<0.0001$ \\
\hline & $\begin{array}{c}\text { No. of cups } \\
\text { (Percentage drinking tea) }\end{array}$ & $\begin{array}{l}1.18 \\
(65 \%)\end{array}$ & $\begin{array}{l}0.78 \\
(53 \%)\end{array}$ & $\begin{array}{l}-34 \% \\
-18 \%\end{array}$ & $\begin{array}{l}<0.0001 \\
<0.0001\end{array}$ \\
\hline & Of which tea outside meals & 0.92 & 0.64 & $-30 \%$ & $<0.0001$ \\
\hline & Of which tea with meals & \begin{tabular}{|l|}
0.26 \\
$(14.9 \%)$
\end{tabular} & $\begin{array}{l}0.14 \\
(10.2 \%)\end{array}$ & $\begin{array}{l}-46 \% \\
-32 \%\end{array}$ & $\begin{array}{l}<0.0001 \\
<0.0001\end{array}$ \\
\hline
\end{tabular}

Table 7. Food consumption during previous 24 hours as recorded during first and second home visit for children over 24 months of age, anaemic (7a) and not anaemic (7b). 
The increase in fruit and vegetable consumption may not be an effect of the project since we recorded at the same time an increase in staple food that the project did not promote. Junk food consumption declined slightly, with chips and soft drinks up and candies down. Tea consumption decreased by $35 \%$, and tea with meals decreased even more $(-45 \%)$. At the same time water consumption increased. Similar results were recorded in the non-anaemic population.

As shown in Table 8, the children of parents who participated in awareness sessions seem to have had a better improvement of nutritional habits, particularly in terms of reducing tea consumption during meals: $-72 \%$ versus $-32 \%$ when considering cups; $-55 \%$ versus $-10 \%$ when considering the percentage of children drinking tea.

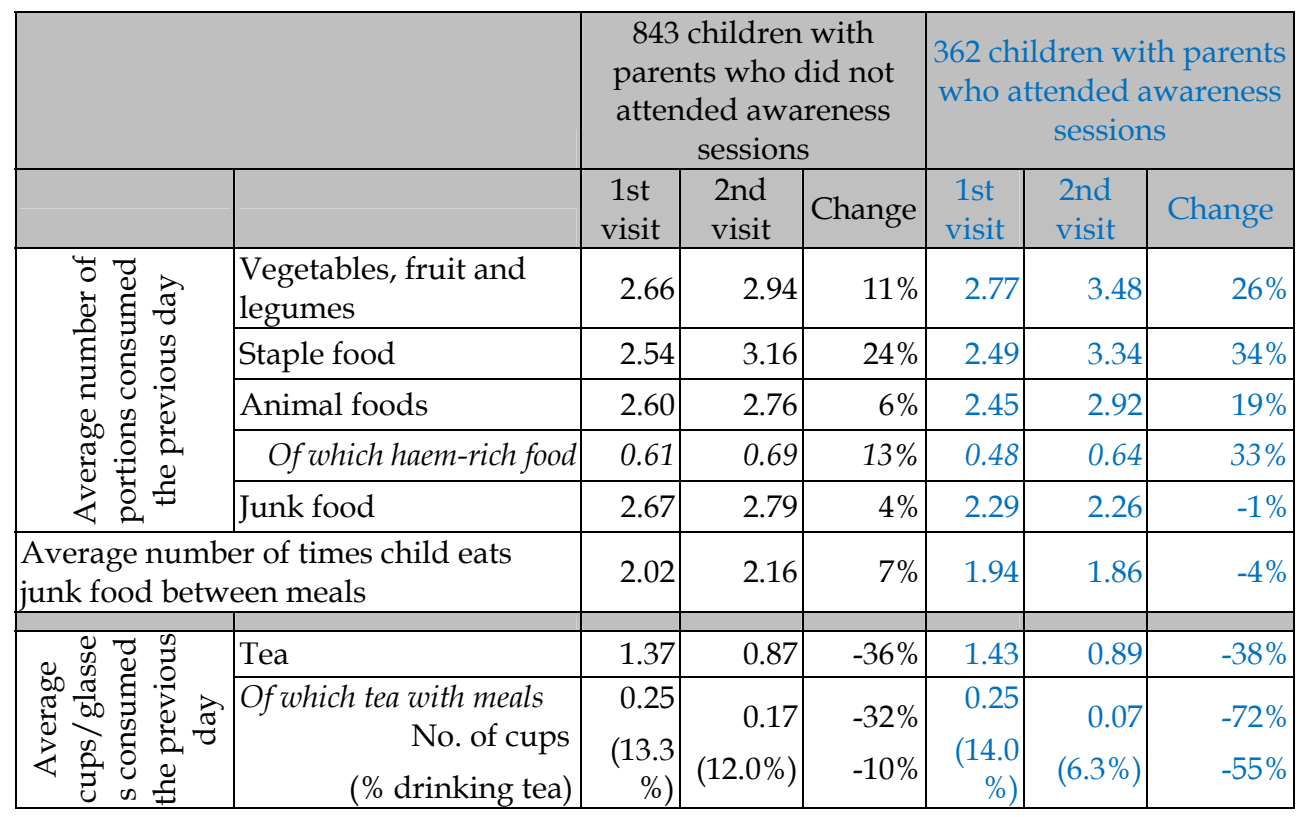

Table 8 . Food consumption during previous 24 hours stratified for participation of parents in awareness sessions.

\subsubsection{Children below 24 months of age at screening}

The overwhelming majority of children were having an average of 3 meals a day and the percentage was stable. However, the percentage of children receiving fewer than 3 meals a day was reduced from $15.5 \%$ to 8.4 . \% (breast feeding was not considered).

As expected, the consumption of all types of food increased, with the exception of junk food, which remained stable. The consumption of soft drinks and candies, however, increased significantly.

Tea consumption was high, even among small children, half of whom had drunk it the previous day. There was an $18 \%$ decrease in quantity, and tea with meals decreased even more $(-40 \%)$. At the same time water consumption increased.

Similar values were found in the non-anaemic population (144 children). 


\begin{tabular}{|c|c|c|c|c|c|}
\hline & & \multicolumn{4}{|c|}{ Anaemic children $<24$ months } \\
\hline & & 1st visit & 2nd visit & change & $\mathrm{P}$ \\
\hline \multicolumn{2}{|r|}{ N. of children } & \multicolumn{2}{|c|}{773} & & \\
\hline \multicolumn{2}{|r|}{ Average no. of meals } & 2.90 & 2.96 & & \\
\hline \multicolumn{2}{|c|}{$\%$ of children having fewer than 3 meals } & $15.5 \%$ & $8.4 \%$ & $-46 \%$ & $<0.0001$ \\
\hline \multirow{8}{*}{ 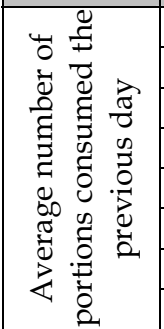 } & Vegetables, fruit and legumes & 2.04 & 2.61 & $28 \%$ & 0.0014 \\
\hline & Staple food & 1.85 & 2.27 & $23 \%$ & $<0.0001$ \\
\hline & Animal foods & 3.00 & 3.28 & $9 \%$ & 0.0014 \\
\hline & Of which rich haem food & 0.53 & 0.64 & $21 \%$ & 0.002 \\
\hline & Junk food & 1.92 & 1.86 & $-3 \%$ & 0.4 \\
\hline & Of which chips & 0.62 & 0.50 & $-20 \%$ & $<0.0001$ \\
\hline & Of which candies & 0.17 & 0.23 & $39 \%$ & 0.001 \\
\hline & Of which soft drinks & 0.06 & 0.09 & $49 \%$ & 0.07 \\
\hline \multicolumn{2}{|c|}{ Number of times child eats junk food between meals } & 1.91 & 1.88 & $-2 \%$ & 0.4 \\
\hline \multirow{6}{*}{ 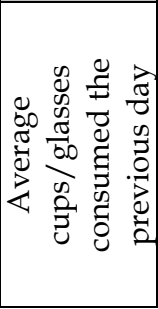 } & Water & 3.73 & 4.69 & $26 \%$ & $<0.0001$ \\
\hline & no. of cups & 0.82 & 0.67 & $-18 \%$ & 0.0008 \\
\hline & (Percentage drinking tea) & $(49 \%)$ & $(47 \%)$ & $-4 \%$ & 0.3 \\
\hline & Of which tea between meals & 0.63 & 0.55 & $-12 \%$ & 0.06 \\
\hline & & 0.19 & 0.12 & $-40 \%$ & 0.0007 \\
\hline & Of which tea with meals & $(12.2 \%)$ & $(8.1 \%)$ & $-34 \%$ & 0.002 \\
\hline
\end{tabular}

Table 9. Food consumption during previous 24 hours as recorded during first and second home visit for anaemic children below 24 months of age.

WE COULD NOT FIND ANY ASSOCIATION BETWEEN IMPROVEMENT OF ANAEMIC STATUS AND CHANGE IN NUTRITIONAL HABIT

\subsection{Anaemia prevalence after 1 year of intervention: a random sample of Phase $1 \mathrm{KGs}$ children}

One of the biggest challenges of any medical intervention is to maintain the benefit obtained in the short term also in the long term. This is particularly important for nutritional supplementation intervention, such as treatment for iron deficiency anaemia: it is reasonable to have an improvement after iron supplementation, but what happens then? It is true that even a temporary improvement in anaemia at a crucial age with regard to growth can have long-lasting benefits, but our task was to assess the level of anaemia 1 year after the end of the intervention.

\subsubsection{Methods}

We randomly selected 178 children who were anaemic when enrolled in October 2009 during the SOUTH GAZA-1 project and had improved by the end of the project (May 2010), and we re-tested them in May 2011, one year after the end of the project. To evaluate improvement we compared anaemia prevalence and haemoglobin level at the three different time points using the pair t-test (comparison of each subject with himself/herself). 


\subsubsection{Results}

It can be seen from Table 10 below and Figure 6 that:

- at the end of phase 1 only 8 children were still anaemic (all of them had an improvement in $\mathrm{Hb}$ level $\geq 1 \mathrm{~g} / \mathrm{dl}$; none had moderate or severe anaemia);

- 1 year later the vast majority of children (88.2\%) were still not anaemic and only 21 had regressed to mild anaemia;

- the level of anaemia increased significantly after 1 year (from $5.5 \%$ to $11.8 \%$; $=0.011$ ) but was still much lower than found at baseline;

- $\quad$ none of the 21 anaemic cases in May 2011 had moderate or severe anaemia and only 2 had an $\mathrm{Hb}$ level below $10 \mathrm{~g} / \mathrm{dl}$, meaning that even the children who were still anaemic were at the limit of normality. The average haemoglobin level among the children was lower than in May 2010, yet much higher than the level recorded at the beginning of the SOUTH GAZA 1 project.

\begin{tabular}{|c|c|c|c|c|c|c|c|}
\hline \multirow{3}{*}{\begin{tabular}{l}
\multicolumn{1}{c}{ Type of anaemia } \\
Severe and moderate \\
anaemia $<9 \mathrm{~g}$
\end{tabular}} & \multicolumn{2}{|c|}{ October 2009} & \multicolumn{2}{|c|}{ May 2010} & \multicolumn{2}{|c|}{ May 2011} & \multirow{2}{*}{$P$ value } \\
\hline & \multicolumn{2}{|c|}{ No. $\%$} & \multicolumn{2}{|c|}{ No. $\quad \%$} & \multicolumn{2}{|c|}{ No. $\quad \%$} & \\
\hline & 18 & $10.1 \%$ & 0 & $0 \%$ & & & \multirow{3}{*}{$<0.0001$} \\
\hline Mild anaemia & 160 & $89.9 \%$ & 8 & $5.5 \%$ & 21 & $11.8 \%$ & \\
\hline No anaemia & 0 & & 170 & $95.5 \% \%$ & 157 & $88.2 \%$ & \\
\hline $\begin{array}{l}\text { Mean Hb level } \\
\text { among } 178 \text { children }\end{array}$ & \multicolumn{2}{|c|}{$9.94 \mathrm{~g} / \mathrm{dl}$} & \multicolumn{2}{|c|}{$11.98 \mathrm{~g} / \mathrm{dl}$} & \multicolumn{2}{|c|}{$11.85 \mathrm{~g} / \mathrm{dl}$} & $<0.0001$ \\
\hline $\begin{array}{l}\text { Mean Hb level among } \\
21 \text { children still } \\
\text { anaemic in May } 2011\end{array}$ & \multicolumn{2}{|c|}{$9.89 \mathrm{~g} / \mathrm{dl}$} & \multicolumn{2}{|c|}{$11.71 \mathrm{~g} / \mathrm{dl}$} & \multicolumn{2}{|c|}{$10.42 \mathrm{~g} / \mathrm{dl}$} & $<0.0001$ \\
\hline
\end{tabular}

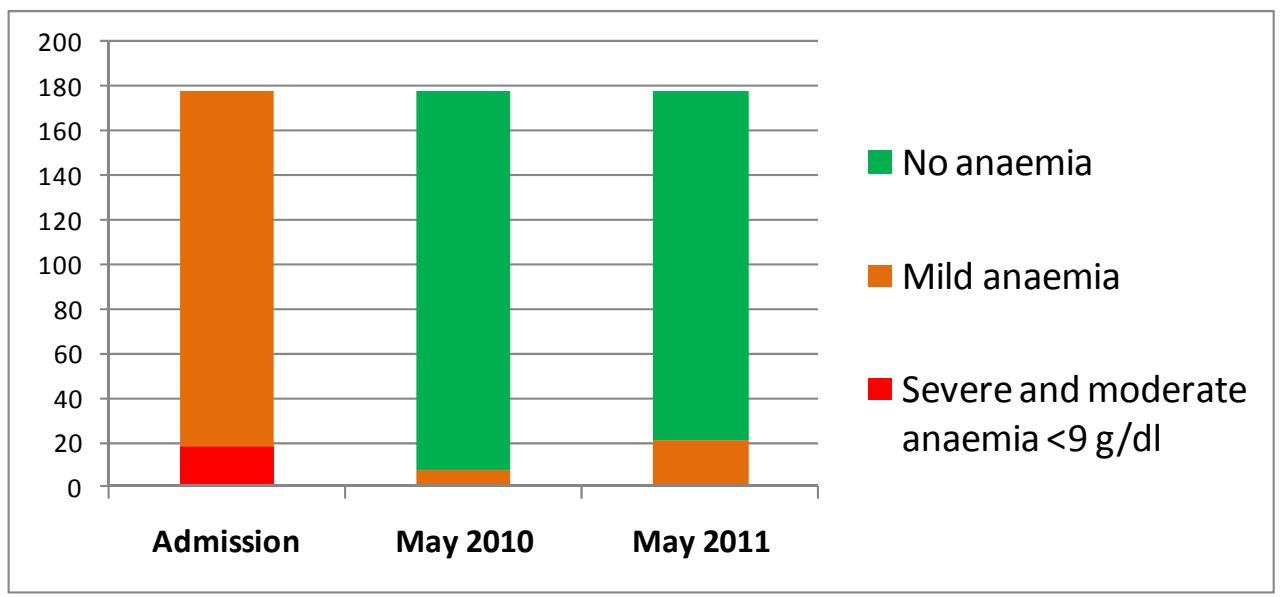

Table 10. and Fig. 6. Anaemia prevalence at three different time points.

Conclusions drawn:

- $\quad$ anaemia improvement achieved during the SOUTH GAZA 1 project persisted after 1 year;

- the overwhelming majority of children were still not anaemic after 1 year; 
- there was still a fraction of children who regressed to anaemia after stopping supplementation, but their $\mathrm{Hb}$ levels were much higher than before project implementation.

\subsection{Follow-up of still anaemic children}

Children who were still anaemic after intervention underwent a more thorough clinical investigation, treatment and a longer follow-up.

Only 50 were diagnosed as having thalassaemia: the $0.48 \%$ of the 10.445 children screened and the $1.01 \%$ of the children found to be anaemic.

Out of the 296 children found to be still anaemic during follow-up screening at the end of the SOUTH GAZA-1 project, 159 (from 140 families) were still attending kindergarten in October 2010 and were enrolled in Phase 2 activities; the others had left, mainly to go to school. One hundred and twenty-nine of them were tested again; the other 33 refused to enter the new program.

After intensive counselling, the majority of children with no improvement in anaemic status were found to:

- $\quad$ have had poor drug adherence and/or

- have high tea consumption during meals and/or

- drink large amounts of tea.

Extra counselling was given to the mothers of these children.

The results for the 129 children re-tested in October 2010 showed a substantial change from their previous status (Table 11):

- $50.4 \%$ of children were no longer anaemic;

- $\quad$ the number of children with severe/moderate anaemia dropped from 17 to 3;

- 19 children were still anaemic, but improved their $\mathrm{Hb}$ value by at least $1 \mathrm{~g} / \mathrm{dl}$;

- $\quad$ only 45 children did not improve.

\begin{tabular}{|c|c|c|c|c|c|}
\hline \multirow{3}{*}{$\begin{array}{c}\text { Type of anaemia } \\
\text { Severe and moderate anaemia }<9 \mathrm{gr}\end{array}$} & \multicolumn{2}{|c|}{ June 2010} & \multicolumn{2}{|c|}{ October 2010} & \multirow{2}{*}{ p value } \\
\hline & No & & No & $\%$ & \\
\hline & 17 & $13.2 \%$ & 3 & $2.3 \%$ & \multirow{3}{*}{$<0.0001$} \\
\hline Mild anaemia & 111 & $86.2 \%$ & 61 & $47.3 \%$ & \\
\hline No anaemia & 1 & $0.8 \%$ & 65 & $50.4 \% \%$ & \\
\hline Mean $\mathrm{Hb}$ level among 129 children & \multicolumn{2}{|c|}{$9.62 \mathrm{~g} / \mathrm{dl}$} & \multicolumn{2}{|c|}{$10.91 \mathrm{~g} / \mathrm{dl}$} & $<0.0001$ \\
\hline
\end{tabular}

Table 11. Haemoglobin level and anaemic status of children not improving in the first phase.

\section{Discussion}

\subsection{Anaemia prevalence}

Our sample cannot be considered as fully representative of the under- 5 population of the Gaza Strip because they were not randomly selected, and because children below 12 months of age were under-represented. We found an anaemia prevalence at screening of $43.7 \%$, which was strongly associated with children's younger age (from $76.2 \%$ at $6-11$ months to $17.0 \%$ for children over 5 years of age). 
The prevalence we found is very similar to that reported by the local Ministry of Health (PNA MOH, 2011) for children below 12 months (prevalence $76.2 \%$ among children aged 9-12 months) but much lower for the oldest age group (prevalence 58.6\% among school children in 2009). The lower prevalence noticed in our children over 5 years of age could be explained by the fact that there have been several instances in the last 2 years of ironfortified-food distribution in kindergartens, and we found that children receiving fortified food had a significantly lower level of anaemia. However the fortified food distribution, which was not implemented within a public health scheme, does not seem to be able to tackle completely the problem and several kids were found anaemic despite it.

In addition to child's age and utilisation of fortified food, we found a significant association of anaemia with mother's poor education (an indication that low-social-status subjects are more vulnerable) and with stunting (not surprising since anaemia and stunting both reflect poor quality nutrition).

It is worth noting that children aged between 12 and 48 months, particularly those below 24 months, have very high prevalence of anaemia but are particularly difficult to reach because they do not attend the health clinic regularly (the vaccination program ends in the first year) or go to kindergarten: specific actions to target them should be implemented because anaemia can have very negative consequences for them (Walter, 2003).

Universal growth monitoring at least once a year for all under-5s, including haemoglobin level testing, could be one of the measures to take in the Palestinian context, where medical facilities and health workers are readily available and could easily provide this service. This would also provide the opportunity to monitor and contrast stunting, an age-old chronic problem, at an early stage, and also obesity, the new rampant one.

\subsection{Anaemia improvement}

Overall performance for anaemia was very good. Nearly $70 \%$ of the children treated were cured within 4-6 months. A review of the literature shows that this rate is in line, if not better, with what has been achieved in specific studies elsewhere (Rosadoet al, 2010) or in the region where children received iron daily or weekly (Faqih et al, 2006; Tavil et al, 2003), but these were clinical trials with a small number of participants and effectiveness in the field is always more complicated.

One good result seen is an impact of the supportive counselling, including home visits: this is backed up by the fact that mothers who gained a better knowledge had an additional $24 \%$ chance of having a child who recovered from anaemia. The effect of well-motivated parents - something rarely studied in trials, where almost all participants are well motivated - is confirmed by the better results achieved when parents participated in awareness sessions.

Of course we have to be careful in considering this difference as a result of the awareness sessions, since it is likely that we had a strong selection bias: parents most interested in "nutritional" topics even before the project probably attended more awareness sessions, and they were also more attentive in monitoring their children's adherence and nutritional habits.

The lower rate of improvement in children below 24 months of age confirms the high vulnerability of this age group.

The use of more palatable iron with fewer side effects, such as that used in our projects (Toblli et al, 2007), can explain the relatively good adherence and impact: and the link between adherence and improvement was clearly proven during our interventions. 
As found in another study (Zlotkin et al, 2003), further supplementation is not needed to maintain non-anaemic status in most children previously treated for anaemia: almost all the children who recovered from anaemia were not anaemic 1 year later.

\subsection{Nutritional habits: knowledge and practice}

Knowledge of anaemia and nutrition was quite low, particularly for less educated mothers, but health education achieved a substantial increase in the level of knowledge, particularly in the less educated.

The 24-hour nutritional questionnaire was designed as a tool for diagnosis and family counselling, not for gathering information, but it provided some interesting data on food consumption:

- $\quad$ high prevalence of junk food in the under-5s, as also noticed for school children (PNA $\mathrm{MOH}, 2011)$;

- low consumption of fruit and vegetables;

- high consumption of tea, half of the children below 24 months of age having drunk some during the previous day.

During the second home visit we found a consistent decrease in tea consumption in all age categories, particularly during meals, but we were unable to establish a real reduction in junk food consumption and there was only a minimal increase in the intake of fruit and vegetables.

It is important to point out that food consumption was reported by the mothers, so the reported "good change" should be treated with caution because this could in part be the result of the mother's desire to give the (counselling) interviewer a good impression.

Our data confirm that increased knowledge did not immediately result in improved feeding habits, a constraint found in many interventions that try to address chronic nutritional problems such as obesity in children (Branca et al, 2007).

Little change in nutritional habits and the weakness of having only two monitoring measures of habits could explain why we were unable to establish a significant association between change in nutritional habit and anaemia improvement.

\section{Acknowledgment}

The article preparation was not funded by the donors in any way, and all its contents are published under the responsibility of Terre des Hommes Italia and the Palestinian Medical Relief.

Thanks go to the staff of PMRS, Tdh-It and kindergarten who implemented the projects

\section{References}

Abdeen, Z., Greenough, G., Shahin, M., Tayback M; 2002. Nutritional Assessment of the West Bank and Gaza Strip. Accessed on the internet on the 07/07/2007 at: http://www.usaid.gov/wbg/reports/Nutritional_Assessment.pdf

Azeredo CM, Cotta RM, Sant'Ana LF, Franceschini Sdo C, Ribeiro Rde C, Lamounier JA, Pedron FA. Greater effectiveness of daily iron supplementation scheme in infants. Rev Saude Publica. 2010 Apr;44(2):230-9.

Faqih AM, Kakish SB, Izzat M. Effectiveness of intermittent iron treatment of two- to sixyear-old Jordanian children with iron-deficiency anemia. Food Nutr Bull. 2006 Sep;27(3):220-7. 
Palestinian National Authority, 2011. National Nutrition Surveillance System. 2010 Report. Ministry of Health, Nutrition Department

Rahim HF, Wick L, Halileh S, Hassan-Bitar S, Chekir H, Watt G, Khawaja M. Maternal and child health in the occupied Palestinian territory. Lancet. 2009 Mar 14;373(9667):967-77. Epub 2009 Mar 4. Erratum in: Lancet. 2009 Jun 27;373(9682):2200.

Roberts, L. and Hofmann, C.A.; 2004. Assessing the impact of humanitarian assistance in the health sector. Emerg Themes Epidemiol. 1:3. Available from: http://www.eteonline.com/content/1/1/3

Robertson, D.W., Bedell, R., Lavery, J.V., Upshur. R.; 2002. What kind of evidence do we need to justify humanitarian medical aid? Lancet. 360, 330-333

Rosado JL, González KE, Caamaño Mdel C, García OP, Preciado R, Odio M. Efficacy of different strategies to treat anemia in children: a randomized clinical trial. Nutr J. 2010 Sep 23;9:40.

Rychetnik, L., Frommer, M., Hawe, P., Shiell, A.; 2002. Criteria for evaluating evidence on public health interventions. J Epidemiol Community Health. 56,119-127.

Tavil B, Sipahi T, Gökçe H, Akar N. Effect of twice weekly versus daily iron treatment in Turkish children with iron deficiency anemia. Pediatr Hematol Oncol. 2003 Jun;20(4):319-26.

Toblli JE, Brignoli R. Iron(III)-hydroxide polymaltose complex in iron deficiency anemia / review and meta-analysis. Arzneimittelforschung. 2007;57(6A):431-8. Review

Verster, A.; 1996. Guidelines for the control of iron deficiency in countries of the Eastern Mediterranean, Middle East and North Africa. World Health Organization, Regional Office for the Eastern Mediterranean. WHO-EM/NUT/177, E/G/11.96/1000.

Walter T. Effect of iron-deficiency anemia on cognitive skills and neuromaturation in infancy and childhood. Food Nutr Bull. 2003 Dec;24(4 Suppl):S104-10. Review.

WHO and UNICEF; 2004. Focusing on anaemia. Towards an integrated approach for effective anaemia control. Accessed on the internet on the 05/10/2011 at: http://www.who.int/medical_devices/publications/en/WHO_UNICEFanaemiastatement.pdf

Francesco Branca, Haik Nikogosian and Tim Lobstein, 2007. The challenge of obesity in the WHO European Region and the strategies for response. WHO Regional Office for Europe, Copenhagen, Denmark

WHO, 2009. Multicentre Growth Reference Study Group. WHO Child Growth Standards: Growth velocity based on weight, length and head circumference: Methods and development. Geneva: World Health Organization, 2009.

WHO, UNICEF, United Nations University; 2001. Iron deficiency anaemia: assessment, prevention, and control. Geneva, World Health Organization. WHO/NHD/01.3.

WHO; 2009. Health conditions in the occupied Palestinian territory, including east Jerusalem, and in the occupied Syrian Golan. Provisional agenda item 14 A62/24: Provisional agenda item 13 A59/INF.DOC./21 May 2009. Accessed on the internet on the 05/08/2011 at: h http://apps.who.int/gb/ebwha/pdf_files/A62/A62_R2en.pdf 


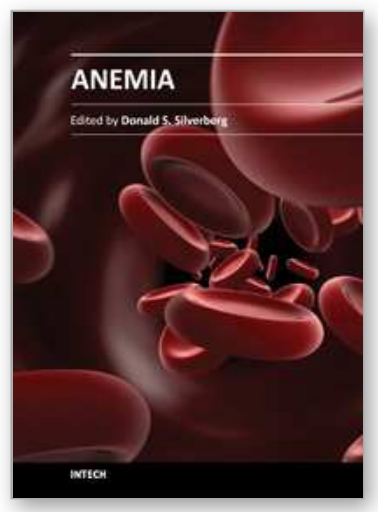

\author{
Anemia \\ Edited by Dr. Donald Silverberg
}

ISBN 978-953-51-0138-3

Hard cover, 440 pages

Publisher InTech

Published online 29, February, 2012

Published in print edition February, 2012

This book provides an up- to- date summary of many advances in our understanding of anemia, including its causes and pathogenesis, methods of diagnosis, and the morbidity and mortality associated with it. Special attention is paid to the anemia of chronic disease. Nutritional causes of anemia, especially in developing countries, are discussed. Also presented are anemias related to pregnancy, the fetus and the newborn infant. Two common infections that cause anemia in developing countries, malaria and trypanosomiasis are discussed. The genetic diseases sickle cell disease and thalassemia are reviewed as are Paroxysmal Nocturnal Hemoglobinuria, Fanconi anemia and some anemias caused by toxins. Thus this book provides a wide coverage of anemia which should be useful to those involved in many fields of anemia from basic researchers to epidemiologists to clinical practitioners.

\title{
How to reference
}

In order to correctly reference this scholarly work, feel free to copy and paste the following:

Michele Magoni, Ghassam Zaqout, Omar Ahmmed Mady, Reema Ibraheem Al Haj Abed and Davide Amurri (2012). Supplementation and Change of Nutritional Habits for the Prevention and Treatment of Iron Deficiency Anaemia in Gaza Children: A Case Study, Anemia, Dr. Donald Silverberg (Ed.), ISBN: 978-953-51-0138-3, InTech, Available from: http://www.intechopen.com/books/anemia/supplementation-and-change-of-nutritionalhabits-for-the-prevention-and-treatment-of-iron-deficiency

\section{INTECH}

open science | open minds

\section{InTech Europe}

University Campus STeP Ri

Slavka Krautzeka 83/A

51000 Rijeka, Croatia

Phone: +385 (51) 770447

Fax: +385 (51) 686166

www.intechopen.com

\section{InTech China}

Unit 405, Office Block, Hotel Equatorial Shanghai

No.65, Yan An Road (West), Shanghai, 200040, China

中国上海市延安西路65号上海国际贵都大饭店办公楼405单元

Phone: +86-21-62489820

Fax: $+86-21-62489821$ 
(C) 2012 The Author(s). Licensee IntechOpen. This is an open access article distributed under the terms of the Creative Commons Attribution 3.0 License, which permits unrestricted use, distribution, and reproduction in any medium, provided the original work is properly cited. 